九州大学学術情報リポジトリ

Kyushu University Institutional Repository

\title{
Global Challenges with Ageing Water Storage Infrastructure
}

Parera, Duminda

United Nations University - Institute for Water Environment and Health (UNU-INWEH) : Senior Researcher

https://doi.org/10.5109/4738547

出版情報: Proceedings of International Exchange and Innovation Conference on Engineering \& Sciences (IEICES). 7, pp. 30-31，2021-10-21. 九州大学大学院総合理工学府 バージョン：

権利関係 : 


\section{Keynote Speaker}

\section{Duminda Parera}

Senior Researcher

United Nations University - Institute for Water Environment and Health

(UNU-INWEH), ON, Canada

E-mail: duminda.perera@unu.edu

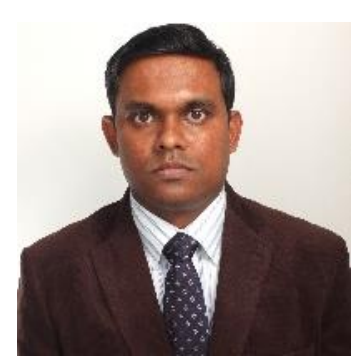

\section{Short Biography}

Duminda Perera is a water resource professional with 15 years of research and technical assistance experience with a primary focus area on water-related disasters. He is a civil engineering graduate of the University of Moratuwa, Sri Lanka, and holds Masters and Doctoral degrees in Urban and Environmental Engineering from Kyushu University, Japan. Dr. Perera's expertise covers surface and subsurface hydrology, numerical modeling, disaster risk reduction, early warning systems, climate change impact assessments, integrated flood management, and capacity development. Before joining UNU-INWEH, he worked for many years in Japan as a research specialist at the UNESCO International Centre for Water Hazard and Risk Management (ICHARM) on various water-related disaster and climate change projects. Since joining UNU, he has been working on climate change, disaster risk reduction, and water resources variability. Dr. Perera also serves as a member of the Climate Change Expert Group of the World Meteorological Organization (WMO) and a focal point of the Expert Group for Disaster Risk Reduction formed by UNDRR. He is an Adjunct Professor at McMaster University and Ottawa University. His current commitments at UNU-INWEH are conducting projects on operational flood early warning systems, ageing water storage infrastructure, and water-related threats to megacities, and various other water-related disasters, their impacts, and risk reduction actions. Dr. Perera published extensively on water-related disasters and disaster risk reduction. 


\title{
Global Challenges with Ageing Water Storage Infrastructure
}

\begin{abstract}
The ageing of surface water storage infrastructure is an emerging global development issue as tens of thousands of existing large dams have reached or exceeded an "alert" age threshold of 50 years. Many others will approach 100 years soon. These aged structures are incurring rapidly rising maintenance needs and costs while simultaneously declining their effectiveness and posing potential threats to human safety and the environment. Analysis of existing global dam datasets indicates that despite plans in some countries to build more dams, mainly for hydropower generation, there will not be another "dam revolution" to match the scale of the high-intensity dam construction experienced in the mid 20th century. At the same time, many of the large dams constructed then are aging, and hence we are already experiencing a "mass ageing" of water storage infrastructure. The emerging practice of decommissioning of ageing dams which can either be removal or re-operation to address issues of ensuring public safety, escalating maintenance costs, reservoir sedimentation and restoring a natural river ecosystem, is essential to investigate further. Decommissioning becomes the option if economic and practical limitations prevent a dam from being upgraded or if its original use has become obsolete. The cost of dam removal is estimated to be an order of magnitude less than that of repairing. While dam decommissioning is a relatively recent phenomenon, it is gaining pace in the USA and Europe, where many dams are older. However, it is primarily small dams that have been removed to date, and the decommissioning of large dams is still in its infancy, with only a few known cases in the last decade. With the mass ageing of dams well underway, developing a framework of protocols that will guide and accelerate the dam decommissioning process is essential.
\end{abstract}

